Article

\title{
Evaluating the Hydrologic Benefits of a Bioswale in Brunswick County, North Carolina (NC), USA
}

\author{
Rebecca A. Purvis ${ }^{1, *}$, Ryan J. Winston ${ }^{2}\left(\mathbb{D}\right.$, William F. Hunt ${ }^{3}$, Brian Lipscomb ${ }^{4}$, \\ Karthik Narayanaswamy ${ }^{5}$, Andrew McDaniel ${ }^{4}$, Matthew S. Lauffer ${ }^{4}$ and Susan Libes ${ }^{6}$ \\ 1 Atkins Engineering SNC-Lavalin, Raleigh, NC 27609, USA \\ 2 Department of Food, Agricultural, and Biological Engineering, Ohio State University, \\ Columbus, OH 43210, USA; Winston.201@osu.edu \\ 3 Department of Biological and Agricultural Engineering, North Carolina State University, \\ Raleigh, NC 27695, USA; wfhunt@ncsu.edu \\ 4 North Carolina Department of Transportation, Raleigh, NC 27610, USA; blipscomb@ncdot.gov (B.L.); \\ ahmcdaniel@ncdot.gov (A.M.); mslauffer@ncdot.gov (M.S.L.) \\ 5 AECOM, Morrisville, NC 27560, USA; karthik.narayanaswamy@aecom.com \\ 6 Department of Coastal and Marine Systems Science, Coastal Carolina University, Conway, SC 29528, USA; \\ susan@coastal.edu \\ * Correspondence: rebecca.purvis@atkinsglobal.com; Tel.: +1-832-350-2406
}

Received: 6 May 2019; Accepted: 17 June 2019; Published: 20 June 2019

check for updates

\begin{abstract}
Bioswales are a promising stormwater control measure (SCM) for roadway runoff management, but few studies have assessed performance on a field scale. A bioswale is a vegetated channel with underlying engineered media and a perforated underdrain to promote improved hydrologic and water quality treatment. A bioswale with a rip-rap lined forebay was constructed along state highway NC 211 in Bolivia, North Carolina, USA, and monitored for 12 months. Thirty-seven of the 39 monitored rain events exfiltrated into underlying soils, resulting in no appreciable overflow or underdrain volume. The bioswale completely exfiltrated a storm event of $86.1 \mathrm{~mm}$. The one event to have underdrain-only flow was $4.8 \mathrm{~mm}$. The largest and third-largest rainfall depth events (82.6 and $146 \mathrm{~mm}$, respectively) had a large percentage ( $85 \%$ ) of volume exfiltrated, but also had appreciable overflow and underdrain volumes exiting the bioswale, resulting in no peak flow mitigation. Overall, this bioswale design was able to capture and manage storms larger than the design storm $(38 \mathrm{~mm})$, showing the positive hydrologic performance that can be achieved by this bioswale. The high treatment capabilities were likely due to the high infiltration rate of the media and the underlying soil, longer forebay underlain with media, gravel detention layer with an underdrain, and shallow slope.
\end{abstract}

Keywords: bioretention; bioswale; hydrology; runoff; stormwater

\section{Introduction}

The United Nations predicts that by $2050,66 \%$ of the world's population will be living in urban areas [1]. This increase in urban population will cause an increase in impervious cover resulting from urban sprawl. An increase in impervious cover can have detrimental environmental effects [2-6]. Changes in land cover likely alter storm hydrographs, resulting in increased runoff volumes, peak flows, and a decreased time to peak flow [7-9], causing an increased occurrence of flooding [10]. The continued urbanization and consequent negative hydrologic impacts highlight the need for stormwater control measures.

Low impact development (LID) is a design philosophy to manage stormwater near its source [11]. The overarching goal of LID is to develop land in such a way that the developed land's hydrologic condition mimics those of pre-development conditions as closely as possible [12,13]. Stormwater control 
measures (SCMs) are employed to achieve LID principles through practices that convey, infiltrate, and treat runoff $[14,15]$.

One commonly installed SCM is a bioretention cell (BRC), which is a sand-based practice amended with fractions of silt and clay (fines) and organic matter [16]. Hydrologically, the high sand content supports a high infiltration rate that serves to reduce runoff volume and control outflow peak flows [16]. Previous bioretention studies have reported $24-99 \%$ peak flow rate reductions [17-23] and 20-98\% volume reduction $[20,24,25]$.

Another common SCM is a dry swale, which is a vegetated channel for stormwater conveyance [26,27]. Dry swales have reported mean volume reduction from 11 to $75 \%$ [13,15,28-33]. Swale peak flow rate reductions have been reported from 10 to $74 \%$, with detention provided by infiltration or check dams improving this mitigation [31,34,35].

A bioswale combines the conveyance of a dry swale with the infiltration capabilities of bioretention media [36]. The grassed surface conveys stormwater runoff and can reduce runoff rates due to vegetation roughness [37]. Beneath the vegetation is an engineered soil media, generally with a high sand content to promote infiltration and benefit volume and peak flow rate mitigation [38]. A bioswale generally employs a perforated underdrain below the media. While the performance of swales and bioretention cells has been relatively well studied, there is a lack of data on the performance of bioswales. Initial research on bioswales has demonstrated the potential for stormwater runoff volume reduction [39-41]. This research implemented a bioswale in the Coastal Plains of North Carolina and monitored the hydrologic capabilities for a range of rainfall depths when placed over sandy soil.

\section{Materials and Methods}

\subsection{Site Descritption}

\subsubsection{Watershed Characteristics}

The studied bioswale was built in Brunswick County in Bolivia, North Carolina (NC), USA $\left(34^{\circ} 0^{\prime} 16.2972^{\prime \prime} \mathrm{N}, 78^{\circ} 15^{\prime} 38.7792^{\prime \prime} \mathrm{W}\right)$. Runoff from this location drains into the Lockwoods Folly River. The Lockwoods Folly River is on the USEPA 303(d) list of impaired waters because of fecal coliform [42]. Brunswick County was reported as the 31st fastest-growing county in the United States from 2010 to 2016 [43].

The bioswale was installed in a right-of-way along state highway NC 211, near the US 17 intersection. NC 211 is a two-lane road with good condition asphalt wearing course. The catchment drainage area was 0.74 ha, with $44 \%$ impervious cover. Pervious cover was existing grassed shoulders, which had a 4:1 horizontal distance:vertical distance $(\mathrm{H}: \mathrm{V})$ slope with good condition vegetation and underlying sandy soils. Stormwater runoff from the lane adjacent to the bioswale discharged onto the grassed shoulder, which could allow for initial infiltration. Runoff then flowed into the rip-rap lined forebay and bioswale (Figure 1).

\subsubsection{Bioswale Design}

The bioswale SCM included a $10.7 \mathrm{~m}$, Class A rip-rap (5.1 to $15.2 \mathrm{~cm}$ diameter stone [44]) lined forebay draining into the bioswale. The bioswale had a total length of $42 \mathrm{~m}$, width of $1.2 \mathrm{~m}$, and depth of $0.9 \mathrm{~m}$. The initial $23.8 \mathrm{~m}$ of the bioswale trench and its trapezoidal base were filled with high-flow media (Figure 2). The remaining trench base was filled with $0.3 \mathrm{~m}$ of ASTM standard \#57 washed stone (2.3 to $38 \mathrm{~mm}$ stone size [45]), designed to serve as detention through internal water storage, which studies have shown to improve runoff reduction within BRCs through the promotion of inter-event exfiltration [35,46]. An $18 \mathrm{~m}$ long perforated underdrain $(0.2 \mathrm{~m}$ diameter) was placed in the middle of this stone layer. A $5 \mathrm{~cm}$ choking layer of pea gravel covered with a fiberglass mesh screen was used to ensure that no media mobilized to the underdrain. The remaining $0.45 \mathrm{~m}$ of trench depth was filled with high-flow media (Table 1) and covered with a thin-cut centipede (Eremochloa ophiuroides) 
sod. The surface of the bioswale was a triangular in shape with 4:1 H:V side slopes (Figure 3 and Table 2). Previously published research on the water quality performance of this bioswale includes a full description of the bioswale construction and additional profiles [47].

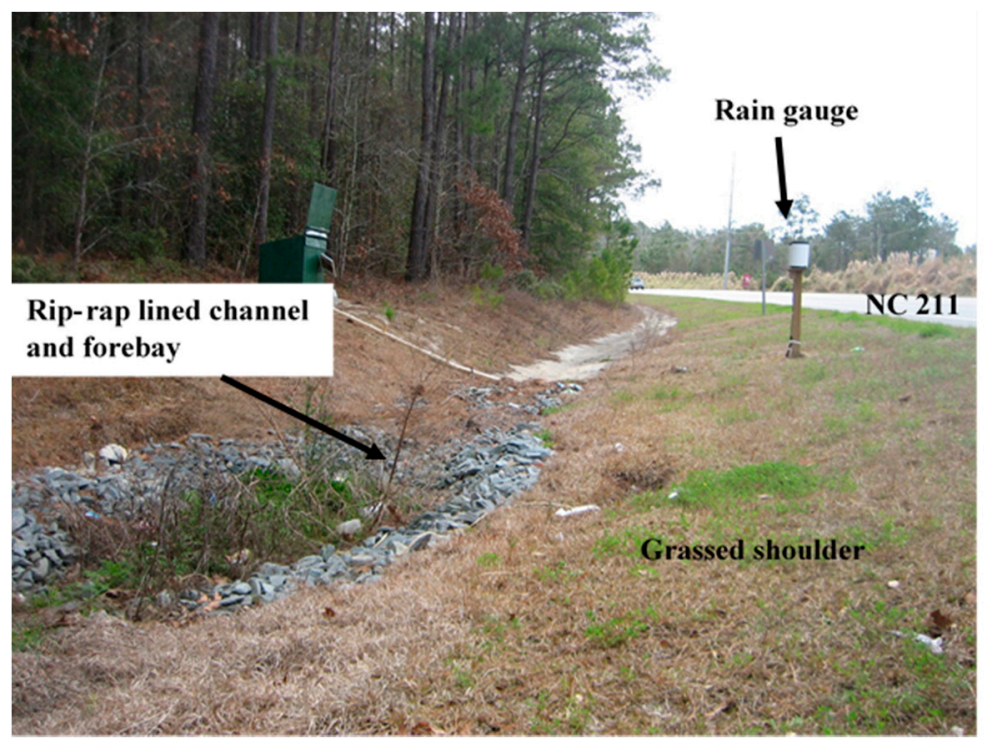

Figure 1. Watershed, grassed shoulder, and rip-rap channel and forebay [47].

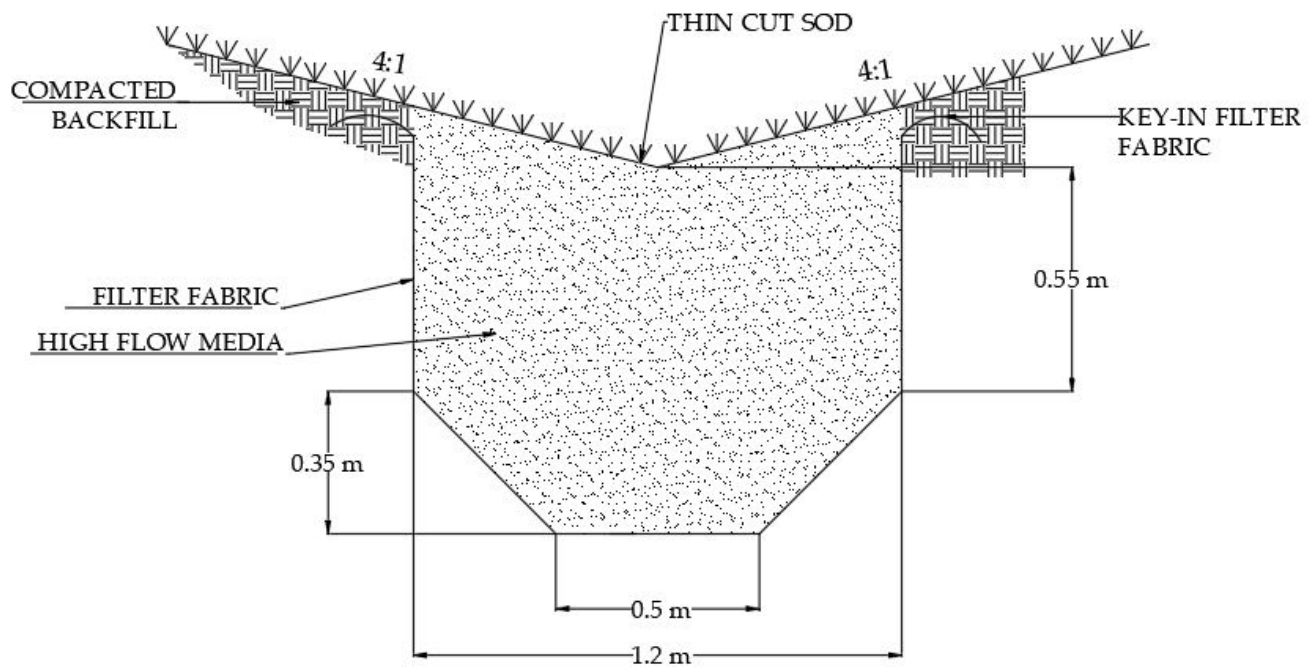

Figure 2. Horizontal cross-section of the first $23.8 \mathrm{~m}$ of the bioswale.

Table 1. High-flow media characteristics.

\begin{tabular}{cc}
\hline Characteristic & Value \\
\hline Hydraulic conductivity $\left(\mathrm{K}_{\text {sat }}\right)$ & $2540 \mathrm{~mm} \mathrm{~h}^{-1}$ \\
Moisture content & $30-50 \%$ \\
Passing 2.0 mm sieve & $95-100 \%$ \\
Passing 1.0 mm sieve & $>80 \%$ \\
Sand-fine & $<5 \%$ \\
Sand-medium & $10-15 \%$ \\
Sand-coarse & $15-25 \%$ \\
Sand-very coarse & $40-45 \%$ \\
Gravel & $10-20 \%$ \\
Clay/silt & $<2 \%$ \\
\hline
\end{tabular}




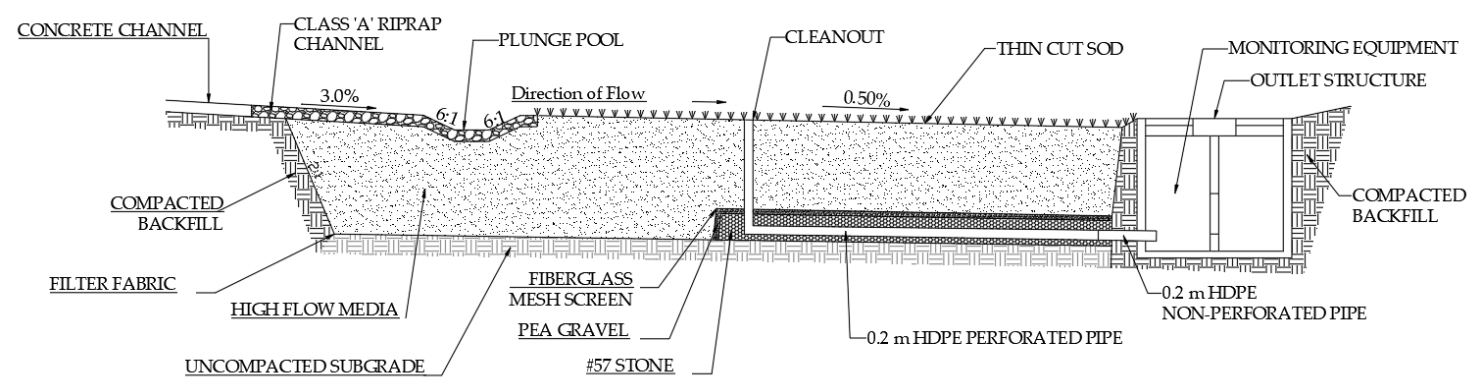

Figure 3. Bioswale longitudinal cross-section [47].

Table 2. Bioswale design characteristics [47].

\begin{tabular}{cc}
\hline Characteristic & Value \\
\hline Rip-rap channel length & $6 \mathrm{~m}$ \\
Rip-rap channel slope & $3 \%$ \\
Plunge pool length & $4.7 \mathrm{~m}$ \\
Plunge pool depth & $0.15 \mathrm{~m}$ \\
Underdrain length & $18.3 \mathrm{~m}$ \\
Underdrain diameter & $0.2 \mathrm{~m}$ \\
Media depth & $0.45-0.9 \mathrm{~m}$ \\
Total length & $42 \mathrm{~m}$ \\
Surface geometry & Triangular \\
Surface side slopes & $4: 1$ \\
Media void storage & $22.7 \mathrm{~m}^{3}$ \\
Surface storage & $14.2 \mathrm{~m}^{3}$ \\
\hline
\end{tabular}

The total bioswale storage was $36.9 \mathrm{~m}^{3}$, with $22.7 \mathrm{~m}^{3}$ of media porosity storage and $14.2 \mathrm{~m}^{3}$ of surface storage. These calculations are conservative since they assume no water is leaving the SCM by exfiltration during a storm event. This calculation is similar to that of the bioretention abstraction volume (BAV) originally postulated by Davis et al. (2012b) [32]. The bioswale's overflow and underdrain flows were discharged into the existing outlet drain structure (Figure 4). The upslope chamber of the outlet structure held the underdrain monitoring equipment, while the downslope chamber had overflow monitoring equipment to prevent mixing of the two outflow sources for monitoring purposes (Figures 3 and 4). A watertight wooden structure was built over the underdrain monitoring vault, creating a de facto $0.15 \mathrm{~m}$ tall check dam for surface storage in the bioswale.

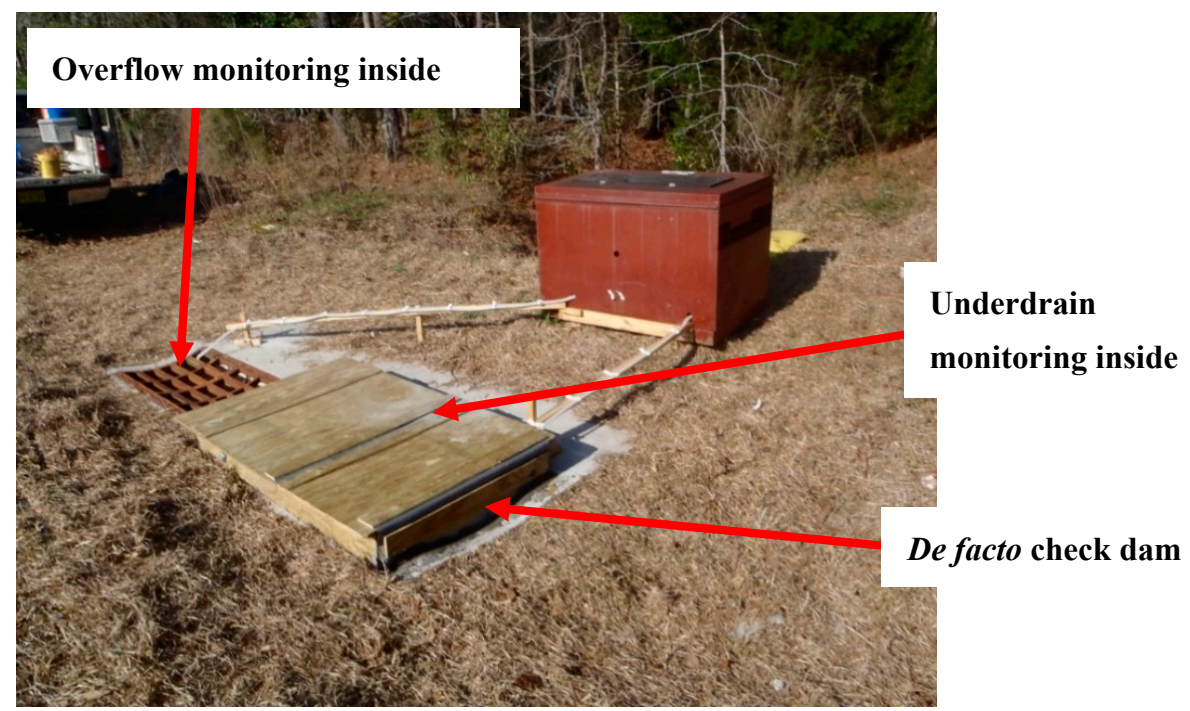

Figure 4. Outlet structure with closed portion for underdrain flow [47]. 


\subsection{Hydrologic Data Collection}

An on-site tipping-bucket rain gauge continuously recorded rainfall, with readings taken at 2 minute intervals. The inlet peak flow rate was calculated based on measured rainfall intensity, using the rational method [48] (Equation (1)):

$$
Q=k C i A
$$

where $Q$ is the peak flow rate $\left(\mathrm{L} \mathrm{s}^{-1}\right), k$ is the English to metric units conversion (0.00278), $C$ is the composite runoff coefficient, $i$ is the 5 minute peak rainfall intensity $\left(\mathrm{mm} \mathrm{h}^{-1}\right)$, and $A$ is the drainage area (ha). Based on site characteristics, a composite runoff coefficient of 0.486 was obtained using $C=$ 0.95 for asphalt $(0.32 \mathrm{ha})$ and $C=0.125$ for grass on a sandy soil with average slope ( $0.42 \mathrm{ha})$.

The inflow volume was calculated using the discrete curve number method [48] (Equation (2)):

$$
Q^{*}=\frac{(P-0.2 S)^{2}}{(P+0.8 S)} ; S=\frac{1000}{C N}-10
$$

where $Q^{*}$ is the runoff depth $(\mathrm{mm}), P$ is the rainfall depth $(\mathrm{mm}), S$ is the maximum retention after rainfall begins $(\mathrm{mm})$, and $C N$ is the curve number. $Q^{*}$ and the corresponding runoff volume were calculated separately for each land use (pervious and impervious) and combined to obtain the total storm runoff for each event. Curve numbers of 39 and 98 were used for the pervious areas and impervious road, respectively.

The underdrain and overflow monitoring structures included purpose-built weirs. Each weir had a HOBO U20 [49] pressure transducer to monitor the flow depth over the weir plate (Figure 5), which was then utilized to calculate the overflow and underdrain volumes and flow rates. Since the transducers were non-vented, another U20 logger was installed by the rain gauge to measure on-site atmospheric pressure. All measurements were taken on at $2 \mathrm{~min}$ intervals. The pressures at each monitoring point were offset by atmospheric pressure to determine flow depth. HOBOware [49] was used to convert the pressure to a corresponding flow depth, which was then used to calculate flow rates and volumes using the same equations as Teledyne ISCO samplers (Equations (3)-(5)).

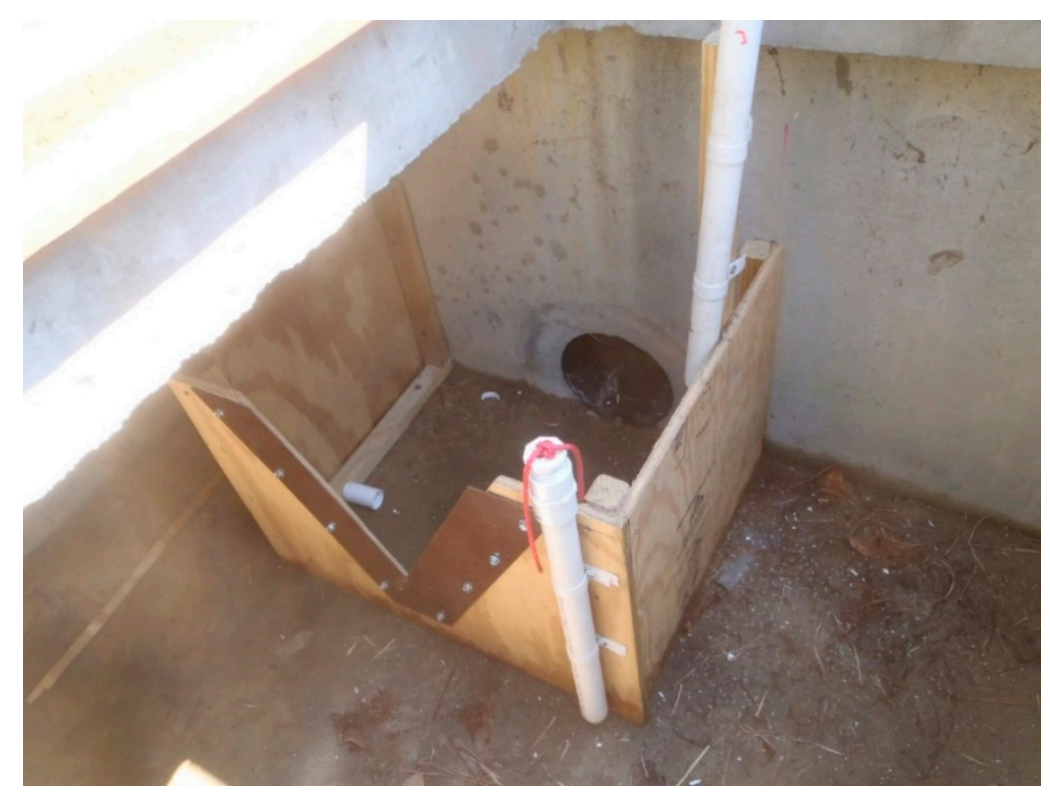

Figure 5. Underdrain outlet weir and associated HOBO logger [47]. 
The flow depth over each corresponding weir was calculated to a flow rate using the following equations for underdrain flow (60 V-notch, Equation (3)) and overflow $\left(90^{\circ} \mathrm{V}\right.$-notch, Equation (4)):

$$
\begin{aligned}
& Q=796.7 \times H^{2.5} \\
& Q=1380 \times H^{2.5}
\end{aligned}
$$

where $Q$ is the flow rate in $\mathrm{L} \mathrm{s}^{-1}$ and $H$ is the flow depth in $\mathrm{m}$.

The volume passing over each weir was determined using the flow rate data and the measurement interval of 2 min (Equation (5)).

$$
V=Q \times t
$$

where $V$ is the corresponding volume (L), $Q$ is the corresponding flow rate $\left(\mathrm{L} \mathrm{s}^{-1}\right)$, and $t$ is the time step of the $120 \mathrm{~s}$ ( $2 \mathrm{~min}$ ) measurement interval. The total volume was the summation of the individual 2 minute steps across the underdrain flow and overflow durations.

A small, $0.9 \mathrm{~m}$ depth well, the same depth of the bioswale, was installed just downstream of the forebay, before the start of the underdrain. A HOBO U20 transducer was used to measure the stage of water within the bioswale media and to monitor the rate of water recession after storms (i.e., the drawdown rate) due to exfiltration.

Monitoring data (rainfall and runoff hydrology) were collected over a 1 year period (25 February 2014 through 26 February 2015).

\subsection{Data Analysis}

A rain gauge was used to determine total rainfall depth. Individual storms had an antecedent dry period (ADP) of 6 hours or greater. Once separated into individual events, 5 minute peak rainfall intensity, rainfall duration, and ADP were determined for each of the 71 observed rainfall events over the 1 year monitoring period. Rainfall depth totaled $1085 \mathrm{~mm}$ during this time, well below the $1547 \mathrm{~mm}$ annual average precipitation from 1971 to 2000 recorded in Wilmington, NC, located $43 \mathrm{~km}$ away [50]. However, roughly one-half of the studied year (177 days) did not have complete rainfall data due to equipment failures.

Hydrologic data from the underdrain and overflow bubbler modules were analyzed for the presence (or absence) and quantity of flow during each storm event. Detectable flow was initiated when the water level exceeded the invert of the weir. Thus, rainfall depth could be related to the size of the storm that (1) generated detectable underdrain flow and/or (2) generated detectable overflow to occur. Of the 71 storms with inflow data, 39 events had paired HOBO underdrain and overflow data.

Using the HOBO data, the following were calculated: total inlet volume, overflow volume, underdrain volume, inlet peak flow rate, overflow peak flow rate, underdrain peak flow rate, percent of inlet volume exfiltrated, and peak flow rate reductions. The exfiltrated volume, the difference between the inflow volume and the total outflow (overflow plus underdrain) (Equation (6)), represents the water which left the bioswale network into the in situ soil, assuming no loss via evaporation over the observational timescale.

$$
V_{\text {exfiltrated }}=V_{\text {inflow }}-V_{\text {overflow }}-V_{\text {underdrain }} \text {. }
$$

Peak flow rate reductions were calculated using Equation (7):

$$
\text { Peak flow rate reduction }=\left(\frac{\text { Inlet peak flow rate }- \text { Out flow peak flow rate }}{\text { Inlet peak flow rate }}\right) \times 100 \% .
$$

Wilcoxon signed rank non-parametric tests were utilized to determine if either the peak flow rate reductions or the percent of inflow exfiltrated to the underlying soil were statistically significant. All statistical analyses were completed using R software (v. 3.4.3, R Core Team, 2013) using a 95\% significant criterion $(\alpha=0.05)$. 


\subsection{Analysis for Bioswale Degradation}

Over time, a bioswale has the potential for clogging due to sediment build-up, which can decrease its infiltration rate and hydrologic function. The ratio of overflow volume to underdrain volume was calculated for each storm event as a potential measure of degradation. A Kendall's tau non-parametric test was utilized to compare the storm event number to the ratio. If surface clogging occurred, it was hypothesized that the ratio would increase with time.

\section{Results and Discussion}

\subsection{Storm Event Characteristics}

Thirty-nine storm events were analyzed for appreciable overflow and/or underdrain volumes (Table 3). Thirty-six events ( $>92 \%$ of events) were completely infiltrated, meaning they did not have appreciable overflow or underdrain volume. The volume from these events passed through the high-flow media and fabric, exfiltrating into the sandy underlying soils. The median storm size for completely infiltrated events was $5.6 \mathrm{~mm}$ of rainfall (range: $1-86.1 \mathrm{~mm}$ ). The overflow or underdrain volume was considered to be appreciable if it was equal to or greater than $1 \%$ of the total inflow volume and greater than 0.25 watershed $\mathrm{mm}$ of rainfall to eliminate "incidental" outflows. Three events had appreciable underdrain volume. The median depth for these events was $82.6 \mathrm{~mm}$ (range: $4.8-146 \mathrm{~mm}$ ). Of these three events, one had underdrain-only flow, leaving two events with appreciable underdrain and overflow. The one event with underdrain-only was $4.8 \mathrm{~mm}$. The median storm size for the two events with appreciable outflow was $114 \mathrm{~mm}$ (range: 82.6-146 mm).

Table 3. Fate of inflow based on HOBO data.

\begin{tabular}{ccccc}
\hline Event Type & Number of Events & $\begin{array}{c}\text { Median } \\
(\mathbf{m m})\end{array}$ & $\begin{array}{c}\text { Mean } \\
(\mathbf{m m})\end{array}$ & $\begin{array}{c}\text { Range } \\
(\mathbf{m m})\end{array}$ \\
\hline Inflow a & 39 & 5.6 & 17.8 & $0.76-146$ \\
Completely infiltrated & 36 & 5.6 & 12.7 & $1.0-86.1$ \\
$\begin{array}{c}\text { Underdrain-only flow } \\
\text { Overflow }\end{array}$ & 1 & 4.8 & 4.8 & 4.8 \\
& 2 & 114 & 114 & $82.6-146$ \\
\hline
\end{tabular}

a_-Inflow events with complete HOBO monitoring equipment data for all monitoring points (inflow, overflow, underdrain).

Based on the watershed characteristics and the bioswale design, the system could be expected to capture and treat up to a $13.7 \mathrm{~mm}$ storm [48]. This depth is representative of a storm that fills the surface storage and fully utilizes the porosity of the media. All events within this rainfall depth were captured by the bioswale, with only one having appreciable underdrain volume (Table 3), showing that the design completely captured design storms, as well as exfiltrating much larger events (up to $86.1 \mathrm{~mm}$ ). While this large storm of $86.1 \mathrm{~mm}$ is much greater than the expected capture volume, precipitation from this event occurred for an extended duration (19 hours), allowing the runoff time to infiltrate the media and exfiltrate to the underlying soil.

Of the 39 storm events, peak flow mitigation occurred for 37 events (Table 4). For the largest and third-largest events ( 82.6 and $146 \mathrm{~mm}$ ), no peak flow mitigation occurred. These are the same two events reported in Table 3 as having overflow. The smaller event was $82.6 \mathrm{~mm}$ with a peak intensity of $93 \mathrm{~mm} \mathrm{~h}^{-1}$, duration of $19.3 \mathrm{~h}$, and ADP of 3.76 days. The larger event was $146 \mathrm{~mm}$ with a peak intensity of $120 \mathrm{~mm} \mathrm{~h}^{-1}$, duration of $34.1 \mathrm{~h}$, and ADP of 0.84 days. 
Table 4. Mean volume and flow for each storm event scenario.

\begin{tabular}{ccccccccc}
\hline Event Type & $\begin{array}{c}\text { Inlet } \\
\text { Peak } \\
\text { Flow } \\
\text { Rate } \\
\left(\mathbf{L ~ s}^{-1}\right)\end{array}$ & $\begin{array}{c}\text { Total } \\
\text { Inlet } \\
\text { Volume } \\
(\mathbf{L})\end{array}$ & $\begin{array}{c}\text { Overflow } \\
\text { Peak } \\
\text { Flow } \\
\text { Rate } \\
\left(\mathbf{L ~ s}^{-1}\right)\end{array}$ & $\begin{array}{c}\text { Total } \\
\text { Overflow } \\
\text { Volume } \\
(\mathbf{L})\end{array}$ & $\begin{array}{c}\text { Underdrain } \\
\text { Peak Flow } \\
\text { Rate } \\
\left(\mathbf{L ~ s}^{-1}\right)\end{array}$ & $\begin{array}{c}\text { Total } \\
\text { Underdrain } \\
\text { Volume } \\
(\mathbf{L})\end{array}$ & $\begin{array}{c}\text { Overflow } \\
\text { Peak Flow } \\
\text { Rate } \\
\text { Reduction } \\
\text { (\%) }\end{array}$ & $\begin{array}{c}\text { Underdrain } \\
\text { Peak Flow } \\
\text { Rate } \\
\text { Reduction } \\
\text { (\%) }\end{array}$ \\
\hline $\begin{array}{c}\text { All inflow events } \\
(\mathrm{n}=39)\end{array}$ & 4.05 & 59,211 & 1.2 & 1642 & 0.91 & 1246 & 89 & 91 \\
\hline $\begin{array}{c}\text { Completely infiltrated } \\
(\mathrm{n}=36)\end{array}$ & 3.79 & 46,100 & 0 & 0 & 0 & 0 & 100 & 100 \\
$\begin{array}{c}\text { Underdrain-only flow } \\
(\mathrm{n}=1) \\
\text { Overflow } \\
(\mathrm{n}=2)\end{array}$ & 3.00 & 6570 & 0 & 0 & 0.02 & 821 & NA & 99 \\
\hline & 11.6 & 460,574 & 21.9 & 32,055 & 16.5 & 23,899 & NR & NR \\
\hline
\end{tabular}

*NA-not applicable; NR-no reduction.

A statistically significant $(\alpha=0.05)$ exfiltrated volume was reported only for the category containing all inflow events (Table 5). All other categories had large percentages of exfiltrated volumes, but due to the small sample size, statistics were not conducted.

Table 5. Mean fate of inflow volume and outlet volume of the 39 events.

\begin{tabular}{|c|c|c|c|}
\hline \multirow{2}{*}{ Event Type } & \multicolumn{2}{|c|}{ Outflow Volume } & \multirow{2}{*}{$\begin{array}{l}\text { Inflow Volume Exfiltrated } \\
\qquad(\%)\end{array}$} \\
\hline & Overflow (\%) & Underdrain (\%) & \\
\hline All inflow events $(n=39)$ & 18 & 82 & 99 \\
\hline Completely infiltrated $(n=36)$ & 0 & 0 & 100 \\
\hline Underdrain-only flow $(\mathrm{n}=1)$ & 0 & 100 & 99 \\
\hline Overflow $(n=2)$ & 58 & 42 & 85 \\
\hline
\end{tabular}

Graphical analysis of the distribution of overflow, underdrain, and exfiltrated water supports that the majority of volume mitigation occurred through exfiltration (Figure 6). While overflow composed over one-half of outflow for the overflow events and underdrain flow was appreciable for three events, this volume was noticeably lower than the cumulative rainfall and exfiltration. In total, $99 \%$ of inflow was filtered by the soil media, providing water quality treatment [47].

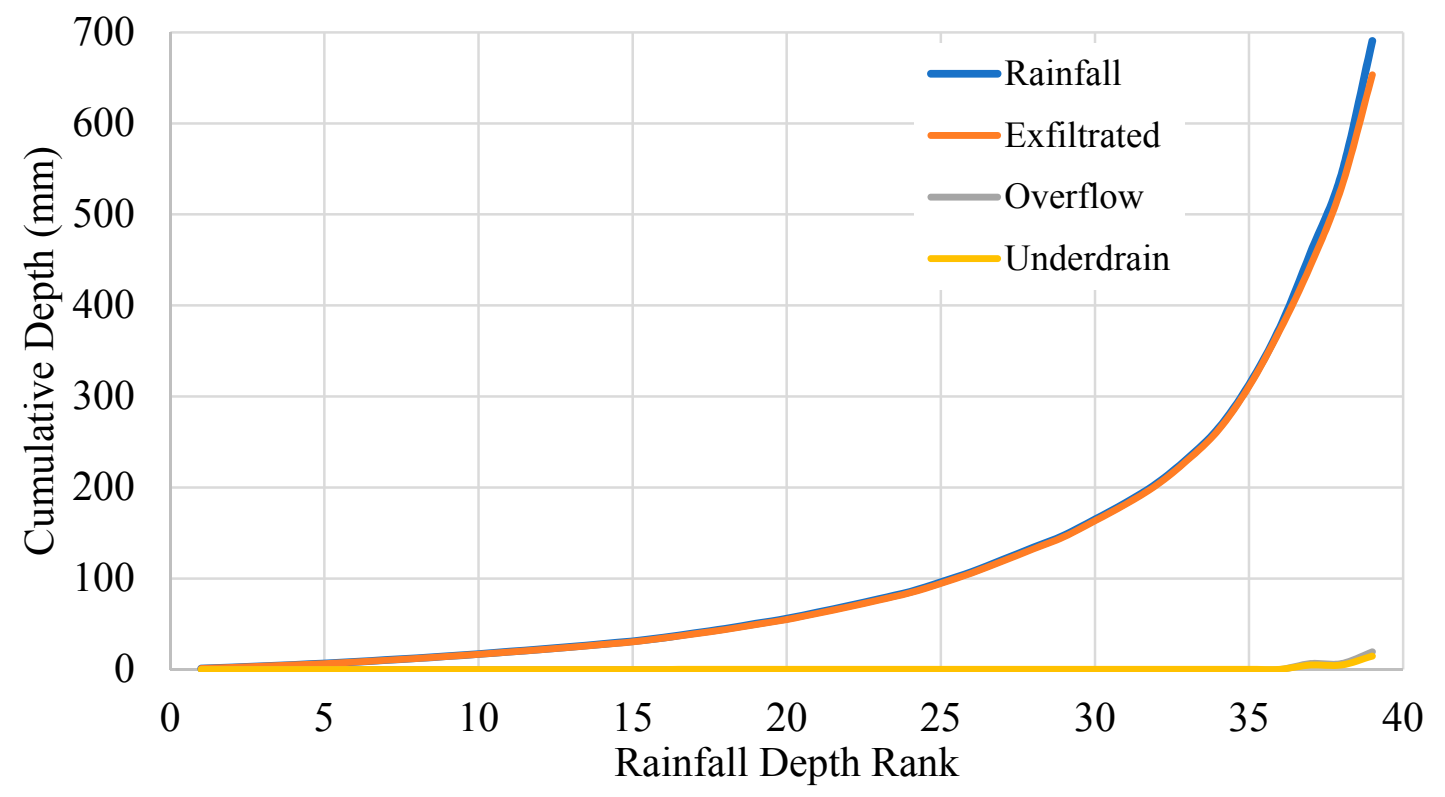

Figure 6. Distribution of rainfall into overflow, underdrain, and exfiltration. 
The six storms with the highest 5 minute rainfall intensities recorded ranged from 73.2 to $120.4 \mathrm{~mm}$ $\mathrm{h}^{-1}$, with two events having an intensity of $73.2 \mathrm{~mm} \mathrm{~h}^{-1}$ (Table 6). Of these six events, only the highest and fourth-highest intensity events resulted in appreciable outflow volume, both overflow and underdrain, with just over one-half of the outflow leaving as overflow. These two events had no peak flow reduction from the overflow, underdrain, or combined outflow. The other four high-intensity events completely exfiltrated all inflow volume.

The five storms with the largest rainfall depths ranged from $146 \mathrm{~mm}$ to $48.3 \mathrm{~mm}$ (Table 7). Only two of these events had appreciable outflow, with more than one-half leaving as overflow. These two events (events 6 and 60) were the same two high-intensity events that resulted in outflow. The two events with overflow were the only events to occur in both the highest rainfall depths and intensities. While these events exfiltrated a large percentage of volume, as noted, neither decreased peak flows. This could be caused by the bioswale being fully saturated, resulting in ponding on the surface and any additional overflow volume not being subject to flow mitigation from the vegetation [51].

This bioswale was able to completely infiltrate four of the six highest intensity events and three of the five largest rainfall depth events. While the exact in situ soil infiltration rate was not determined, these results show the positive volume and flow rate mitigation capabilities of this bioswale. Volume mitigation is likely due to several design features including the high infiltration rate of the media and the underlying sandy soil. The plunge pool was underlain with the high-flow media, allowing all ponded water to infiltrate the bioswale. The underdrain was only present in the second half of the bioswale, allowing for more media volume for storage, infiltration, and increased base surface area for exfiltration. The bioswale had a shallow slope $(0.5 \%)$, likely decreasing the overflow rate and increasing hydraulic retention time for increased infiltration. The gravel layer below the underdrain allowed for the conveyance of infiltrated volume out of the bioswale, aiding in outflow volume mitigation. Additionally, the $0.05 \mathrm{~m}$ gravel layer below the underdrain provided detention for inter-event exfiltration. 
Table 6. Hydrologic performance of the largest peak 5 minute rainfall intensity events.

\begin{tabular}{|c|c|c|c|c|c|c|c|c|c|c|}
\hline Event & $\begin{array}{l}\text { Peak } 5 \text { min } \\
\text { Intensity } \\
(\mathrm{mm} / \mathrm{h})\end{array}$ & $\begin{array}{c}\text { Rainfall } \\
\text { Depth } \\
(\mathrm{mm})\end{array}$ & $\begin{array}{l}\text { Rainfall } \\
\text { Duration } \\
\text { (h) }\end{array}$ & $\begin{array}{l}\text { Antecedent } \\
\text { Dry Period } \\
\text { (ADP) } \\
\text { (days) }\end{array}$ & $\begin{array}{c}\% \\
\text { Over of } \\
\text { Outflow }\end{array}$ & $\begin{array}{c}\% \\
\text { Under of } \\
\text { Outflow }\end{array}$ & $\begin{array}{c}\% \\
\text { Exfiltrated }\end{array}$ & $\begin{array}{l}\text { Overflow } \\
\text { Peak Flow } \\
\text { Rate } \\
\text { Reduction } \\
(\%)\end{array}$ & $\begin{array}{c}\text { Underdrain } \\
\text { Peak Flow } \\
\text { Rate } \\
\text { Reduction } \\
\quad(\%)\end{array}$ & $\begin{array}{c}\text { Combined } \\
\text { Peak Flow } \\
\text { Rate } \\
\text { Reduction } \\
(\%)\end{array}$ \\
\hline 60 & 120.4 & 146 & 34.1 & 0.84 & 57 & 43 & 85 & -47 & -20 & -35 \\
\hline 29 & 112.8 & 13.2 & 0.67 & 0.9 & NA & NA & 100 & 100 & 100 & NA \\
\hline 31 & 97.5 & 21.1 & 1.7 & 0.89 & NA & NA & 100 & 100 & 100 & NA \\
\hline 6 & 93.0 & 82.6 & 19.3 & 3.76 & 58 & 42 & 86 & -141 & -69 & -112 \\
\hline 67 & 73.2 & 86.1 & 18.8 & 5.19 & NA & NA & 100 & 100 & 100 & NA \\
\hline
\end{tabular}

* Intensities for comparison: 1 year-5 min event $=159 \mathrm{~mm} \mathrm{~h}^{-1} ; 1$ year- $24 \mathrm{~h}=4 \mathrm{~mm} \mathrm{~h}^{-1}$.

Table 7. Hydrologic performance of largest overall rainfall depth events.

\begin{tabular}{|c|c|c|c|c|c|c|c|c|c|c|}
\hline Event & $\begin{array}{c}\text { Rainfall } \\
\text { Depth (mm) }\end{array}$ & $\begin{array}{c}\text { Peak } 5 \text { min } \\
\text { Intensity } \\
(\mathrm{mm} / \mathrm{h})\end{array}$ & $\begin{array}{c}\text { Rainfall } \\
\text { Duration } \\
\text { (h) }\end{array}$ & $\begin{array}{c}\text { ADP } \\
\text { (days) }\end{array}$ & $\begin{array}{c}\% \\
\text { Over of } \\
\text { Outflow }\end{array}$ & $\begin{array}{c}\% \\
\text { Under of } \\
\text { Outflow }\end{array}$ & $\begin{array}{c}\% \\
\text { Exfiltrated }\end{array}$ & $\begin{array}{l}\text { Overflow } \\
\text { Peak Flow } \\
\text { Rate } \\
\text { Reduction } \\
\quad(\%)\end{array}$ & $\begin{array}{c}\text { Underdrain } \\
\text { Peak Flow } \\
\text { Rate } \\
\text { Reduction } \\
\text { (\%) }\end{array}$ & $\begin{array}{c}\text { Combined } \\
\text { Peak Flow } \\
\text { Rate } \\
\text { Reduction } \\
(\%)\end{array}$ \\
\hline 60 & 146 & 120.4 & 34.1 & 0.84 & 57 & 43 & 85 & -47 & -20 & -35 \\
\hline 67 & 86.1 & 73.2 & 18.8 & 5.19 & NA & NA & 100 & 100 & 100 & NA \\
\hline 6 & 82.6 & 93.0 & 19.3 & 3.76 & 58 & 42 & 86 & -141 & -69 & -112 \\
\hline 19 & 62.7 & 54.9 & 15.6 & 4.56 & NA & NA & 100 & 100 & 100 & NA \\
\hline 37 & 48.3 & 68.6 & 25.5 & 0.54 & NA & NA & 100 & 100 & 100 & NA \\
\hline
\end{tabular}




\subsection{Internal Water Level}

Monitoring well data were utilized to determine several characteristics including the maximum stage of water in the bioswale during a storm and the resulting drawdown rate. Kendall's tau tests were run to determine any statistically significant interactions in relation to the internal water level in the bioswale. Positive associations were found between rainfall depth and the following: maximum stage of ponded water in the bioswale, length of time to the peak well stage, and internal water drawdown rate.

Analysis of the peak internal water level compared to rain depth showed that the interval water level plateaued around $1.07 \mathrm{~m}$ (Figure 7). The average depth of the bioswale was $0.9 \mathrm{~m}$. Thus, a depth within the well greater than $0.9 \mathrm{~m}$ equated to ponding along the bioswale surface. There were several events $(n=12)$ of ponding on the bioswale surface and complete saturation of the media. The smallest rainfall depth to result in surface ponding was $11.4 \mathrm{~mm}$. The monitoring well was near the upstream end of the bioswale, so ponding at this location was not always representative of overflow, as runoff infiltrates along the bioswale length. Additionally, there was a de facto check dam at the end of the bioswale, allowing for surface ponding. Only two instances of ponding resulted in appreciable overflow, because surface ponding exceeded the storage volume and infiltration capacity. The average

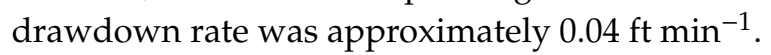

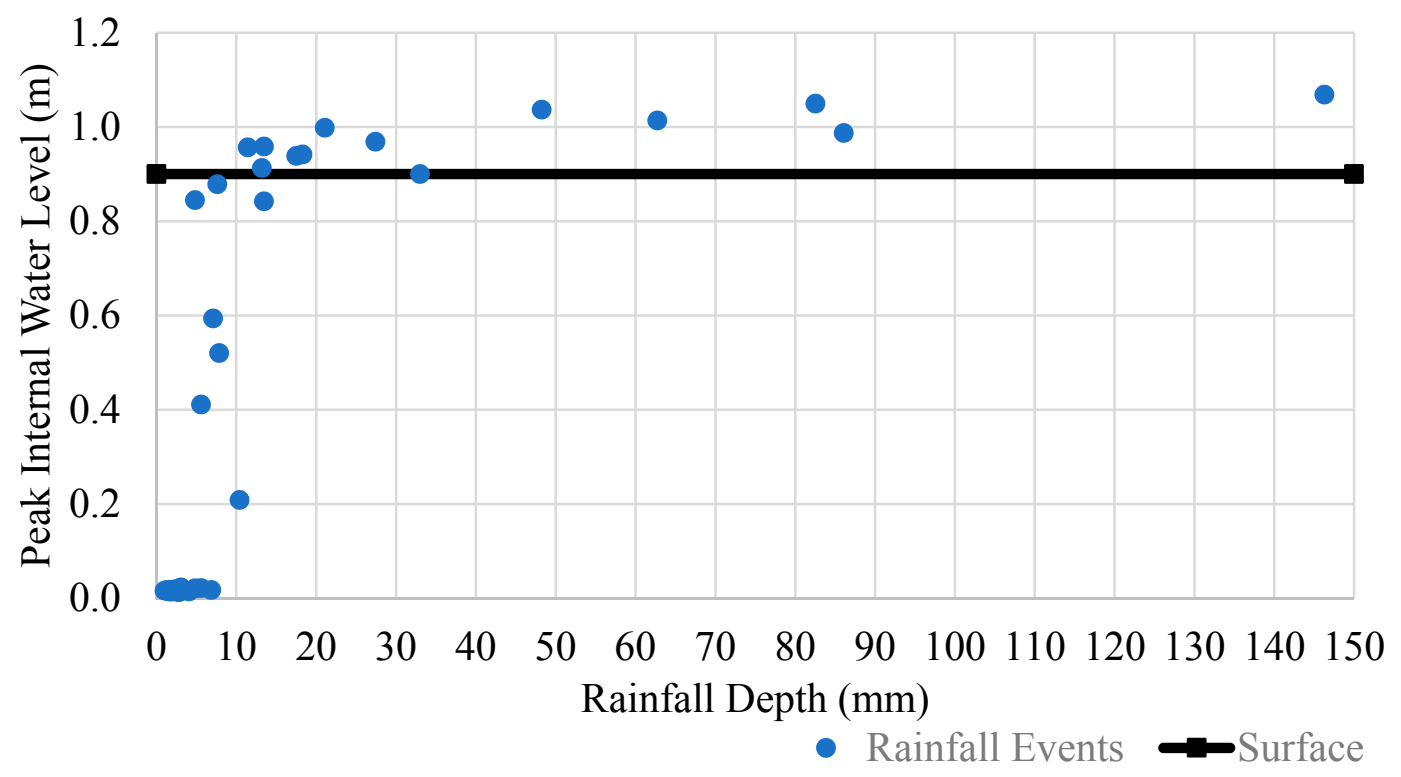

Figure 7. Positive association $(\alpha=0.05)$ between the rainfall depth and the peak bioswale internal water level. Events above the black line (surface) represent surface ponding.

\section{Conclusions}

The bioswale had positive volumetric and flow rate mitigation for the 39 events during the 12 month study period (February 2014-February 2015). The bioswale eliminated overflow from 37 of these 39 storm events, including an event of $86.1 \mathrm{~mm}$. Events with significant overflow were the largest and third-largest rainfall depth events with depths of $146 \mathrm{~mm}$ and $82.6 \mathrm{~mm}$, respectively. Statistical analysis did not show significant decreases in infiltration capabilities of the bioswale over time. Thus, within this study period there was likely little clogging or degradation of the system. Based on the storage available in the media and on the bioswale surface, a storm up to $13.7 \mathrm{~mm}$ could be expected to be fully stored by the bioswale. The bioswale was able to exfiltrate storms much larger than this design event. For example, the $86.1 \mathrm{~mm}$ event was likely able to achieve full exfiltration due to the long rainfall duration of 19 hours, where intra-event exfiltration into the sandy underlying soil was key. 
Monitoring of the internal water level highlighted that ponding occurred on the bioswale surface for the majority of events, with the ponded volume completely infiltrating along the bioswale length for all but two events. This highlighted the capabilities of the bioswale to achieve a high percentage of exfiltrated volume, even in cases where the media was fully saturated and had surface ponding.

This bioswale nearly eliminated outflow volume and had exemplary peak flow mitigation. While this is only one bioswale, this research highlights that bioswale design and function should continue to be examined to allow for the creation of optimal design standards for enhanced hydrologic mitigation. Several design features contributed to positive hydrologic treatment. The high infiltration rate of the media and underlying soil, longer forebay underlain with high-flow media, gravel detention layer with an underdrain in the second half of the bioswale length, and shallow slope allowed large events to be completely captured by the bioswale.

Author Contributions: Author contributions are as follows: conceptualization, M.S.L., A.D., R.J.W., B.L., and W.F.H.; methodology, M.S.L., A.D., R.J.W., B.L., and W.F.H.; software, R.A.P.; validation, R.A.P.; formal analysis, R.A.P.; investigation, R.J.W. and R.A.P.; resources, M.S.L., A.D., R.J.W., B.L., W.F.H., and S.L.; data curation, R.A.P.; writing—original draft preparation, R.A.P.; writing-review and editing, W.F.H., R.J.W., M.S.L., A.D., B.L., K.N., and S.L.; visualization, R.A.P.; supervision, W.F.H.; project administration, M.S.L., A.D., and B.L.; funding acquisition, M.S.L., A.D., and B.L.

Funding: This research was funded by the North Carolina Department of Transportation (NCDOT), Grant 2016-18, and the National Science Foundation (NSF), Grant DGE-1252376.

Acknowledgments: Field equipment installation was performed by Shawn Kennedy (NCSU BAE) and field data collection was performed by Jeff Barley (CCU's Environmental Quality Lab).

Conflicts of Interest: The authors declare no conflict of interest. The sponsors of the project paid for the design and construction of the bioswale. The sponsors also reviewed the manuscript prior to submission, but otherwise had no function in the design of the study; in the collection, analyses, or interpretation of data; in the writing of the manuscript, or in the decision to publish the results.

\section{References}

1. United Nations. World Urbanization Prospects: The 2014 Revision, Highlights; United Nations Department of Economic and Social Affairs, Population Division: New York, NY, USA, 2014. Available online: https://esa.un.org/unpd/wup/publications/files/wup2014-highlights.pdf (accessed on 1 April 2018).

2. Morisawa, M.; LaFlure, E. Hydraulic geometry, stream equilibrium and urbanization. In Adjustments of the Fluvial Systems, Proceedings of the 10th Annual Geomorphology Symposium Series, Binghampton, New York, NY, USA, 21-22 September 1979; Rhodes, D.D., Williams, G.P., Eds.; Kendall/Hunt Publishing Co., Inc.: Dubuque, IA, USA, 1979.

3. Arnold, C.L.; Boison, P.J.; Patton, P.C. Sawmill Brook: An example of rapid geomorphic change related to urbanization. J. Geol. 1982, 90, 155-166. [CrossRef]

4. Bannerman, R.T.; Owens, D.W.; Dodds, R.B.; Hornewer, N.J. Sources of pollutants in Wisconsin stormwater. Water Sci. Technol. 1993, 28, 241-259. [CrossRef]

5. Brabec, E.; Schulte, S.; Richards, P.L. Impervious surfaces and water quality: A review of current literature and its implications for watershed planning. J. Plan. Lit. 2002, 16, 499-514. [CrossRef]

6. Todeschinie, S. Hydrologic and Environmental Impacts of Imperviousness in an Industrial Catchment of Northern Italy. J. Hydrol. Eng. 2016, 21, 05016013. [CrossRef]

7. ASCE. Aspects of hydrologic effects of urbanization. J. Hydr. Eng. Div. ASCE 1975, 101, 449-468.

8. Codner, G.P.; Laurenson, E.M.; Mein, R.G. Hydrologic effects of urbanization: A case study. In Proceedings of the Hydrology and Water Resources Symposium, Canberra, Australia, 1-3 February 1988; pp. 201-205.

9. Mein, R.G.; Goyen, A.G. Urban Runoff; Civil Engineering Transactions, Institution of Engineers: Canberra, Australia, 1988; pp. 225-238.

10. Schueler, T. Controlling Urban Runoff: A Practical Manual for Planning and Designing Urban BMPs; Metropolitan Washington Council of Governments: Washington, DC, USA, 1987.

11. Fletcher, T.D.; Shuster, W.; Hunt, W.F.; Ashley, R.; Butler, D.; Arthur, S.; Trowsdale, S.; Barraud, S.; Semadeni-Davies, A.; Bertrand-Krajewski, J.L.; et al. SUDS, LID, BMPs, WSUD and more-The evolution and application of terminology surrounding urban drainage. Urban Water J. 2015, 12, 525-542. [CrossRef] 
12. Holman-Dodds, J.K.; Bradley, A.A.; Potter, K.W. Evaluation of hydrologic benefits of infiltration based urban storm water management. J. Am. Water Resour. Assoc. 2003, 39, 205-215. [CrossRef]

13. Rushton, B.T. Low-impact parking lot design reduces runoff and pollutants loads. J. Water Resour. Plan. Manag. 2001, 127, 172-179. [CrossRef]

14. Dunnett, N.; Clayden, A. Rain gardens. In Managing Water Sustainably in the Garden and Designed Landscape; Timber: Portland, OR, USA, 2007.

15. Knight, E.M.P.; Hunt, W.F.; Winston, R.J. Side-by-side evaluation of four level spreader-vegetated filter strips and a swale in eastern North Carolina. J. Soil Water Conserv. 2013, 68, 60-72. [CrossRef]

16. Hunt, W.F.; Davis, A.P.; Traver, R.G. Meeting hydrologic and water quality goals through targeted bioretention design. J. Environ. Eng. 2012, 138, 698-707. [CrossRef]

17. Dietz, M.E.; Clausen, J.C. A field evaluation of rain garden flow and pollutant treatment. Water Air Soil Pollut. 2005, 167, 123-138. [CrossRef]

18. University of New Hampshire Stormwater Center (UNHSC). 2005 Data Report; CICEET: Durham, NH, USA, 2006.

19. Davis, A.P. Field performance of bioretention: Hydrology impacts. J. Hydrol. Eng. 2008, 13, 90-95. [CrossRef]

20. Hunt, W.; Smith, J.; Jadlocki, S.; Hathaway, J.; Eubanks, P. Pollutant removal and peak flow mitigation by a bioretention cell in Urban Charlotte, N.C. J. Environ. Eng. 2008, 134, 403-408. [CrossRef]

21. Hatt, B.E.; Fletcher, T.D.; Deletic, A. Hydrologic and pollutant removal performance of stormwater biofiltration systems at the field scale. J. Hydrol. 2009, 365, 310-321. [CrossRef]

22. Lucke, T.; Nichols, P.W.B. The pollution removal and stormwater reduction performance of street-side bioretention basins after ten years in operation. Sci. Total Environ. 2015, 536, 784-792. [CrossRef] [PubMed]

23. Winston, R.J.; Powell, J.T.; Hunt, W.F. Retrofitting a grass swale with rock check dams: Hydrologic impacts. Urban Water J. 2018. [CrossRef]

24. Luell, S.K.; Hunt, W.F.; Winston, R.J. Treating highway bridge deck runoff using bioretention and a swale. In Proceedings of the ASCE 2011 World Environmental and Water Resources Congress, Reston, VA, USA, 22-26 May 2011; pp. 364-374.

25. Jiang, C.; Li, J.; Li, H.; Li, Y.; Chen, L. Field performance of bioretention systems for runoff quantity regulation and pollutant removal. Water Air Soil Pollut. 2017, 228, 468. [CrossRef]

26. Barrett, M.E.; Wals, P.M.; Malina, J.F., Jr.; Charbeneau, R.J. Performance of vegetative controls for treating highway runoff. J. Environ. Eng. 1998, 124, 1121-1128. [CrossRef]

27. Davis, A.P.; Stagge, J.H.; Jamil, E.; Kim, H. Hydraulic performance of grass swales for managing highway runoff. Water Res. 2012, 46, 6775-6786. [CrossRef] [PubMed]

28. Deletic, A. Modelling of water and sediment transport over grassed areas. J. Hydrol. 2001, 248, $168-182$. [CrossRef]

29. Ackerman, D.; Stein, E. Evaluating the effectiveness of best management practices using dynamic modeling. J. Environ. Eng. 2008, 134, 628-639. [CrossRef]

30. Barrett, M.E. Comparison of BMP performance using the international BMP database. J. Irrig. Drain. Eng. 2008, 134, 556-561. [CrossRef]

31. Fassman, E.A.; Liao, M. Monitoring of a series of swales within a stormwater treatment train. In Proceedings of the 32nd Hydrology and Water Resources Symposium, Newcastle, Australia, 30 November-3 December 2009; Engineers Australia: Barton, Australia, 2009; pp. 368-378.

32. Davis, A.P.; Traver, R.G.; Hunt, W.F.; Lee, R.; Brown, R.A.; Olszewski, J.M. Hydrologic performance of bioretention stormwater control measures. J. Hydrol. Eng. 2012, 17, 604-614. [CrossRef]

33. Rujner, H.; Leonhardt, G.; Perttu, A.M.; Marsalek, J.; Viklander, M. Advancing green infrastructure design: Field evaluation of grassed urban drainage swales. In Proceedings of the 9th International Conference on Planning and Technologies for Sustainable Management of Water in the City, Lyon, France, 28 June-1 July 2016.

34. Wu, J.S.; Allan, C.J.; Saunders, W.L.; Evett, J.B. Characterization and pollutant loading estimation for highway runoff. J. Environ. Eng. 1998, 124, 584-592. [CrossRef]

35. Winston, R.J.; Dorsey, J.D.; Hunt, W.F. Quantifying volume reduction and peak flow mitigation for three bioretention cells in clay soils in northeast Ohio. Sci. Total Environ. 2016, 553, 83-95. [CrossRef] [PubMed]

36. Christianson, R.D.; Barfield, B.J.; Hayes, J.C.; Gasem, K.; Brown, G.O. Modeling effectiveness of bioretention cells for control of stormwater quantity and quality. In Critical Transitions in Water and Environmental Resources 
Management, Proceedings of the 2004 World Water and Environmental Resources Congress, Salt Lake City, UT, USA, 27 June-1 July 2004; American Society of Civil Engineers: Reston, VA, USA, 2004.

37. Temple, D.M.; Robinson, K.M.; Ahring, R.M.; Davis, A.G. Stability Design of Grass-lined Open Channels. In Agricultural Handbook, 667; USDA: Washington, DC, USA, 1987.

38. Davis, A.P.; Shokouhian, M.; Sharma, H.; Minami, C. Laboratory study of biological retention for urban stormwater management. Water Environ. Res. 2001, 73, 5-14. [CrossRef] [PubMed]

39. Xiao, Q.; McPherson, E.G. Testing a Bioswale to Treat and Reduce Parking lot Runoff; Center for Urban Forest Research, University of California-Davis: Davis, CA, USA, 2009. Available online: https://www.fs.fed.us/ psw/topics/urban_forestry/products/psw_cufr761_P47ReportLRes_AC.pdf (accessed on 1 April 2018).

40. McLaughlin, J. NYC bioswales pilot project improves stormwater management. Clear Waters 2012, $20-23$.

41. Anderson, B.S.; Phillips, B.M.; Voorhees, J.P.; Siegler, K.; Tjeerdema, R. Bioswales reduce contaminants associated with toxicity in urban storm water. Environ. Toxicol. Chem. 2016, 35, 3124-3134. [CrossRef]

42. United States Environmental Protection Agency (USEPA). North Carolina Water Quality Assessment Report. 2014. Available online: https://iaspub.epa.gov/waters10/attains_state.control?p_state=NC (accessed on 1 April 2018).

43. United States Census Bureau. Resident Population Estimates for the 100 Fastest Growing, U.S. Counties with 10,000 or More Population in 2010: April 1, 2010 to July 1, 2016; Census Bureau Population Division: Washington, DC, USA, 2017. Available online: https://factfinder.census.gov (accessed on 1 April 2018).

44. North Carolina Department of Transportation (NCDOT). Standard Specifications-16 Erosion Control and Roadside Development; North Carolina Department of Transportation: Raleigh, NC, USA, 2012. Available online: https://connect.ncdot.gov/resources/Specifications/Pages/2012StandSpecsMan.aspx?Order= SM-16-1610 (accessed on 1 April 2018).

45. North Carolina Department of Transportation (NCDOT). Division 10 Materials; North Carolina Department of Transportation: Raleigh, NC, USA, 2016. Available online: https:/connect.ncdot.gov/resources/specifications/ 2006\%20specifications\%20books/10.\%20materials.pdf (accessed on 1 April 2018).

46. Brown, R.A.; Hunt, W.F. Underdrain configuration to enhance bioretention exfiltration to reduce pollutant loads. J. Environ. Eng. 2011, 137, 1082-1091. [CrossRef]

47. Purvis, R.A.; Winston, R.J.; Hunt, W.F.; Lipscomb, B.; Narayanaswamy, K.; McDaniel, A.; Lauffer, M.S.; Libes, S. Evaluating the water quality benefits of a bioswale in Brunswick County, North Carolina (NC), USA. Water 2018, 10, 134. [CrossRef]

48. North Carolina Department of Environmental Quality (NCDEQ). NCDEQ Stormwater Design Manual: B-Stormwater Calculations; North Carolina Department of Environmental Quality: Raleigh, NC, USA, 2017. Available online: https://files.nc.gov/ncdeq/Energy\%20Mineral\%20and\%20Land\%20Resources/Stormwater/ BMP\%20Manual/B\%20\%20Stormwater\%20Calculations.pdf (accessed on 1 April 2018).

49. Onset Computer Corporation. HoBoware Pro. Version 3.7.9; Onset Computer Corporation: Bourne, MA, USA, 2016.

50. North Carolina State Climate Office. 1971-2000 Climate Normals. 2016. Available online: http://climate.ncsu. edu/cronos/normals.php (accessed on 1 April 2018).

51. National Cooperative Highway Research Program (NCHRP). NCHRP Report 565-Evaluation of Best Management Practices for Highway Runoff Control; Transportation Research Board: Washington, DC, USA, 2006. Available online: http://nap.edu/23211 (accessed on 1 April 2018).

(C) 2019 by the authors. Licensee MDPI, Basel, Switzerland. This article is an open access article distributed under the terms and conditions of the Creative Commons Attribution (CC BY) license (http://creativecommons.org/licenses/by/4.0/). 